\title{
DETERMINAN BIAYA MODAL EKUITAS: STUDI EMPIRIS PADA PERUSAHAAN PROPERTI, REAL ESTATE DAN KONTRUKSI BANGUNAN
}

\author{
Oleh: \\ Muhammad Syaifur Rohman ${ }^{1}$ \\ Hadi Ismanto ${ }^{2 *}$ \\ Program Studi Manajemen \\ Fakultas Ekonomi dan Bisnis \\ Univesitas Islam Nahdlatul Ulama Jepara \\ Email: \\ syaif.ifur@gmail.com ${ }^{1}$ \\ hadifeb@unisnu.ac.id ${ }^{2}$
}

\begin{abstract}
ABSTRAK
Tujuan dari penelitian ini untuk menguji kembali dan menganalisis pengaruh manajemen laba, ukuran perusahaan dan risiko pasar terhadap biaya modal ekuitas pada perusahaan yang bergerak di sektor property, real estate dan konstruksi bangunan dengan jangka waktu pengamatan selama tahun 2014-2017. Jumlah sampel 40 perusahaan menurut purposive sampling. Data sekunder diolah menggunakan uji regresi linear berganda. Data diperoleh melalui observed dan documented dari laporan keuangan tahunan emiten di IDX maupun situs perusahaan terkait, ICMD, IDN Financial dan data harga saham yang diperoleh dari Yahoo Finance yang dipublikasikan di internet, serta return bebas risiko yang diproksikan dengan tingkat suku bunga Bank Indonesia. Hasil penelitian menunjukkan bahwa manajemen laba dan risiko pasar memiliki pengaruh positif terhadap biaya modal ekuitas, namun tidak oleh variabel ukuran. Temuan ini memberikan kontribusi keilmuan dan bahan kajian bagi perusahaan, peneliti selanjutnya, dan investor/masyarakat. Perusahaan dapat memperhatikan penerapan manajemen laba dan risiko pasar untuk menentukan strategi kebijakan ekuitas. Investor dapat mengambil pilihan yang tepat dengan mempertimbangkan kesehatan perusahaan melalui penerapan manajemen laba dan perubahan kondisi pasar.
\end{abstract}

Kata Kunci: biaya modal ekuitas, manajemen laba, risiko pasar, ukuran perusahaan 


\begin{abstract}
The purpose of this study is to reexamine and analyze the effect of earnings management, company size and market risk on the cost of equity capital in companies engaged in the property, real estate and building construction sectors with an observation period of 2014-2017. The number of samples of 40 companies according to purposive sampling. Secondary data were processed using multiple linear regression tests. The data is obtained through observing and documented from the issuer's annual financial statements on IDX and related company websites, ICMD, IDN Financial and share price data obtained from Yahoo Finance published on the internet, as well as risk-free returns that are proxied by Bank Indonesia's interest rates. The results show that earnings management and market risk have a positive effect on the cost of equity capital, while firm size has no effect on the cost of equity capital. These findings provide scientific contributions and study materials for companies, future researchers, and investors /community. Companies can pay attention to earnings management application and market risk to determine the equity policy strategy. Investors can make the right choice by considering the health of the company through earnings management application and changes in market conditions.
\end{abstract}

Keywords: cost of equity capital, earnings management, firm size, market risk

\title{
A. PENDAHULUAN
}

Dalam menjalankan kegiatan operasional dan dalam rangka meningkatkan usaha suatu perusahaan dibutuhkan dana tambahan yang dapat bersumber dari pihak lain, untuk memperoleh dana perusahaan dapat menerbitkan saham maupun obligasi yang diperdagangkan pada pasar modal. Pasar modal dapat dijadikan sebagai fasilitas yang digunakan untuk memindahkan dana yang memiliki oleh pihak yang memiliki dana berlebih (lender) kepada pihak yang membutuhkan dana tambahan (borrower) (Fahmi, 2012). Salah satu instrumen keuangan yang aktif diperdagangkan di lantai bursa adalah saham. Frekuensi perdagangan saham di bawah standar dikategorikan sebagai saham tidur (Farandani dan Margasari, 2016). Menurut Efrina dan Faisal (2017) investor lebih tertarik pada perusahaan yang likuid, ini menguntungkan bagi perusahaan untuk lebih mudah memperoleh dana dari investor. Informasi lengkap mengenai perusahaan dibutuhkan oleh investor untuk dijadikan sebagai dasar dalam pengambilan keputusan, di antaranya adalah informasi yang ada pada laporan keuangan perusahaan terkait (Kurnia dan Arafat, 2015). Pertimbangan atas informasi tersebut karena adanya risk dan return dari suatu investasi. Untuk mendapatkan tambahan dana dari para investor, perusahaan harus menanggung konsekuensi ekonomi yang kemudian disebut biaya modal ekuitas (Pramita, 2016). 


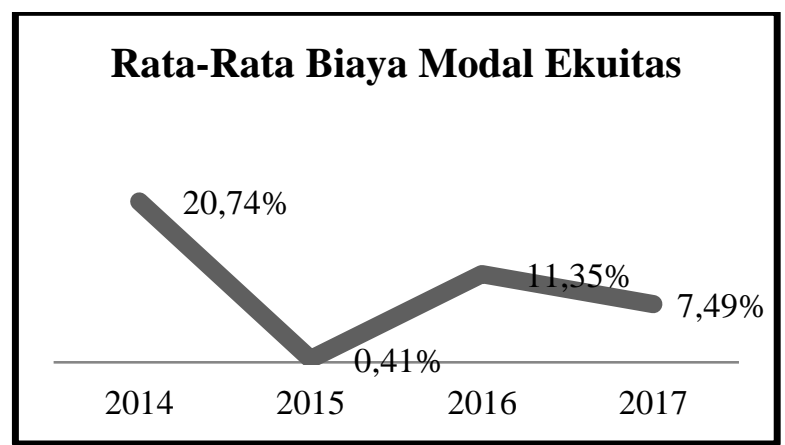

Sumber: Data yang diolah dari IDX, 2019

\section{Gambar 1.}

\section{Grafik Rata-rata Biaya Modal Ekuitas}

Penerbitan saham atau obligasi dapat mengakibatkan perusahaan mengeluarkan biaya tambahan sebagai imbal hasil atas ketersediaan memberikan dana yang dimiliki oleh investor maupun kreditor kepada perusahaan, dana tambahan tersebut disebut biaya modal (Kurnia dan Arafat, 2015). Selama tahun 2014 hingga tahun 2017, perusahaan sektor property, real estate dan kontruksi bangunan mengalami volatilitas. Terdapat suatu fenomena yang menarik dikarenakan biaya modal ekuitas yang berubah-ubah setiap tahunnya sebagaimana terlihat pada Tabel 1. Untuk itu maka peneliti tertarik untuk meneliti faktor apa saja yang bisa memengaruhi biaya modal ekuitas. Besar kecilnya biaya modal ekuitas yang ditanggung oleh perusahaan dapat dipengaruhi oleh manajemen laba (Kurnia \& Arafat, 2015; Rinobel \& Laksito, 2015), ukuran perusahaan (Kurnia \& Arafat, 2015; Rika, 2018; Rinobel \& Laksito, 2015), dan risiko pasar (Rika, 2018; Wulandari, Malikah, \& Mawardi, 2017).

Manajemen melakukan beberapa tindakan dengan tujuan laporan keuangan yang dimiliki terlihat bagus untuk menarik para investor dan kreditor agar menanamkan modalnya. Tindakan yang biasa dilakukan oleh manajer untuk memengaruhi angka pada laporan keuangan adalah dengan manajemen laba (Kurnia dan Arafat, 2015). Penelitian terdahulu yang dilakukan oleh Rinobel dan Laksito (2015) sepakat bahwa manajemen laba berpengaruh positif terhadap biaya modal ekuitas. Tetapi, Kurnia dan Arafat (2015) menunjukkan korelasi negatif antara manajemen laba dan biaya modal ekuitas.

Selanjutnya perbedaan hasil penelitian ditunjukkan oleh Rika (2018), Rinobel dan Laksito (2015) dan Fahdiansyah (2016) yang menyebutkan bahwa ukuran perusahaan berdampspk positif terhadap biaya modal ekuitas. Sementara Kurnia dan Arafat (2015) dan Sukarti dan Suwarti (2018) menunjukkan korelasi negatif antara ukuran perusahaan dan biaya modal ekuitas. Ukuran perusahaan dijadikan sebagai gambaran dari kesejahteraan pemegang saham (Rinobel dan Laksito, 2015). Ukuran perusahaan menunjukkan tingkat aktivitas perusahaan yang diukur dengan berbagai cara, antara lain, aset yang dimiliki, nilai penjualan ataupun dari kapitalisasi pasar. Dalam melakukan investasi, investor tidak hanya memperhatikan hasil yang akan didapatkan, melainkan juga memperhatikan risiko yang akan dihadapi (Rahayu et al., 2018). Risiko pasar terjadi akibat harga pasar substansial yang menurun baik secara keseluruhan saham maupun karena saham tertentu. Rika 
(2018), Fahdiansyah (2016) dan Wulandari et al., (2017) beragumen bahwa risiko pasar berkorelasi positif dengan biaya modal ekuitas. Perbedaan hasil ditunjukkan oleh Meythi, Martusa, \& Evimonita (2012), bahwa risiko pasar berpengaruh negatif terhadap biaya modal ekuitas.

Penelitian ini bertujuan untuk menguji kembali dan menganalisis pengaruh manajemen laba, ukuran perusahaan, dan risiko pasar terhadap biaya modal ekuitas baik secara parsial maupun simultan. Penelitian dilakukan pada perusahaan sektor property, real estate dan konstruksi bangunan yang terdaftar di BEI tahun 2014 hingga 2017.

\section{B. KAJIAN PUSTAKA}

\section{Teori Agensi}

Dalam prakteknya, konflik dalam perusahaan pasti adanya, pertentangan tujuan antara manajer dan shareholders. Konflik ini disebut agency problem (Lei, Lin, \& Wei, 2013). Lei, Lin, \& Wei (2013) menyebutkan bahwa pengambilan keputusan keuangan penting dalam konteks biaya agensi. Empat keputusan keuangan itu adalah leverage, pembayaran dividen, kepemilikan insider, dan kepemilikan institusional. Bouchet (2010) mendefinisikan hubungan keagenan sebagai hubungan dimana satu atau lebih orang prinsipal melibatkan agen untuk melakukan beberapa layanan dengan melibatkan pendelegasian dalam pengambilan keputusan atas nama principal kepada agen. Prinsipal yang dimaksud adalah para pemegang saham yang memberikan dana untuk kegiatan operasional perusahaan. Agen adalah manajemen yang mengelola perusahaan. Sebagaimana kepercayaan pemegang saham, agen berupaya untuk meningkatkan kesejahteraan principal dapat melalui peningkatan nilai dari suatu perusahaan. Sebagai imbal hasilnya agent akan mendapatkan gaji, bonus, dan juga berbagai kompensasi lainnya. Akan tetapi, ketika pemegang saham tidak mengawasi operasional perusahaan secara langsung dapat berpotensi menimbulkan terjadinya konflik kepentingan dan dapat terjadi agency costs. Rebecca dan Siregar (2012) menyatakan bahwa investor yang rasional akan menjaga dirinya dengan meningkatkan biaya ekuitas.

\section{Biaya Modal Ekuitas}

Biaya modal ekuitas atau cost of equity capital yaitu biaya yang dikeluarkan oleh perusahaan guna memenuhi tingkat imbal hasil yang diharapkan oleh para investor, dapat berupa dividen maupun keuntungan modal (capital gain) (Kurnia dan Arafat, 2015). Menurut Sanjaya (2017) perusahaan yang mengalami pertumbuhan akan lebih diminati oleh investor. Hal ini dikarenakan risiko yang ditanggung oleh investor akan berdampak terhadap laba per lembar saham. Jika laba atau keuntungan per lembar saham meningkat maka nilai saham di pasar juga akan meningkat. Biaya modal saham dapat dihitung dengan pendekatan discounted cash flow, bond-yield, dan CAPM (Hanafi, 2011). Pendekatan discounted cash flow menyebutkan biaya modal saham dihitung dengan menjumlah dividend yield dengan tingkat pertumbuhan. Sementara pendekatan bond-yield didasarkan pada asumsi tingkat keuntungan ekspektasi untuk investasi berisiko tinggi akan lebih tinggi daripada tingkat keuntungan investasi berisiko lebih rendah. Untuk 
pendekatan CAPM menggunakan asumsi yang sama dengan bond-yield, dimana tingkat keuntungan ekspektasi untuk saham sama dengan tingkat keuntungan riskfree yang ditambah dengan premi risiko.

\section{Manajemen Laba}

Fahmi (2015) berpendapat bahwa manajemen laba atau earning management adalah tindakan yang dilakukan untuk mengatur laba/keuntungan sesuai dengan kepentingan pihak-pihak tertentu, terutama manajemen dari perusahaan (company management). Tindakan perusahaan ini tentu mengandung motivasi-motivasi tertentu. Tindakan manajemen untuk memaksimumkan laba bertujuan untuk memenuhi tujuan pribadinya, dengan meningkatnya laba perusahaan maka manajemen perusahaan akan mendapatkan bonus atau penghargaan atas partisipasinya terhadap perusahaan, selain itu juga untuk menarik investor agar menanamkan modalnya ke dalam perusahaan karena investor akan menerima deviden yang lebih tinggi atas laba perusahaan tersebut (Rinobel dan Laksito, 2015). Demikian sebaliknya, minimalisasi laba akan memungkinkan perusahaan membagikan dividen lebih rendah atau juga tidak membagikan dividen (Adriani, 2013). Tingginya proksi manajemen laba mengindikasikan biaya modal ekuitas lebih tinggi (Rinobel \& Laksito, 2015), karena kemungkinkan memperoleh pembagian dividen lebih tinggi dimasa mendatang dan investor telah mengantisipasi dengan baik terkait informasi manajemen laba.

\section{$H_{1}:$ Diduga manajemen laba berpengaruh positif terhadap biaya modal ekuitas}

\section{Ukuran Perusahaan}

Kurnia dan Arafat (2015) menyebutkan bahwa ukuran perusahaan menunjukkan besaran ketersediaan informasi. Ketersediaan informasi ini dibutuhkan oleh investor mengevaluasi portofolionya. Pada umumnya, investor lebih menyukai perusahaan yang lebih besar karena kemungkinan tingkat pengembalian yang diperoleh investor dikemudian hari lebih tinggi dibandingkan perusahaan yang lebih kecil (Handayani dan Shaferi, 2011). Perusahaan besar biasanya mempunyai total aset yang besar sehingga para investor tertarik untuk menginvestasikan dananya ke perusahaan tersebut. Ketertarikan ini dikarenakan expected returns yang akan diterima dari perusahaan besar dimasa mendatang lebih besar daripada perusahaan yang lebih kecil. Akan tetapi, Daugherty \& Jithendranathan (2012) menyebutkan bahwa total aset perusahaan menciptakan nilai dan karenanya memungkinan semua pihak untuk mengevaluasi prospek masa depan perusahaan yang lebih pasti. Perusahaan yang besar mungkin menggunakan aset yang dimiliki untuk menanggung kewajibannya dan menahan keuntungannya sehingga dividen yang dibagikan lebih rendah atau tidak sama sekali. Dengan demikian, perusahaan yang besar diperkirakan lebih meminimalisasi biaya modal ekuitas (Kurnia \& Arafat, 2015; Sukarti \& Suwarti, 2018).

\section{$\mathrm{H}_{2}$ : Diduga ukuran perusahaan berpengaruh negatif terhadap biaya modal ekuitas}




\section{Risiko Pasar}

Menurut Rika (2018) risiko pasar (beta) merupakan ukuran risiko yang ditunjukkan dari hubungan antara tingkat return saham terhadap return pasar. Menurut Hartono (2013) menyatakan bahwa risiko pasar (beta pasar) dapat diestimasikan dengan menggunakan model pasar. Di Indonesia return pasar dicerminkan dari return IHSG (Hartono, 2013). Menurut Fahmi (2015), besarnya risiko suatu saham ditentukan oleh beta $(\beta)$, yaitu hubungan antara suatu saham dengan pasarnya. Nilai beta yang lebih dari 1 menunjukkan pergerakan harga saham yang lebih cepat daripada indeks pasar, sedangkan nilai beta yang kurang dari 1 memiliki arti bahwa perubahan harga saham tidak terjadi dengan cepat yang diakibatkan kondisi pasar. Risiko pasar yang tinggi mengakibatkan investor mengharapkan proporsi tingkat pengembalian yang lebih tinggi dan itu berarti biaya modal ekuitas juga tinggi. Begitu juga ketika tingkat risiko rendah akan investor akan meminta keuntungan yang tidak terlalu tinggi sehingga biaya modal ekuitas yang dikeluarkan perusahaan lebih rendah (Rika, 2018; Wulandari et al., 2017).

\section{$\mathrm{H}_{3}$ : Diduga risiko pasar berpengaruh positif terhadap biaya modal ekuitas}

\section{METODE PENELITIAN}

\section{Desain Penelitian}

Penelitian ini bertujuan untuk menguji pengaruh manajemen laba, ukuran perusahaan, dan risiko pasar terhadap biaya modal ekuitas. Penelitian ini menggunakan pendekatan kuantitatif dengan data sekunder yang dikumpulkan dari analisa laporan keuangan tahunan emiten di IDX maupun situs perusahaan terkait, ICMD, IDN Financial dan data harga saham yang diperoleh dari Yahoo Finance yang dipublikasikan di internet, serta return bebas risiko yang diproksikan dengan tingkat suku bunga Bank Indonesia. Adapun desain penelitian ditunjukkan pada Gambar 2.

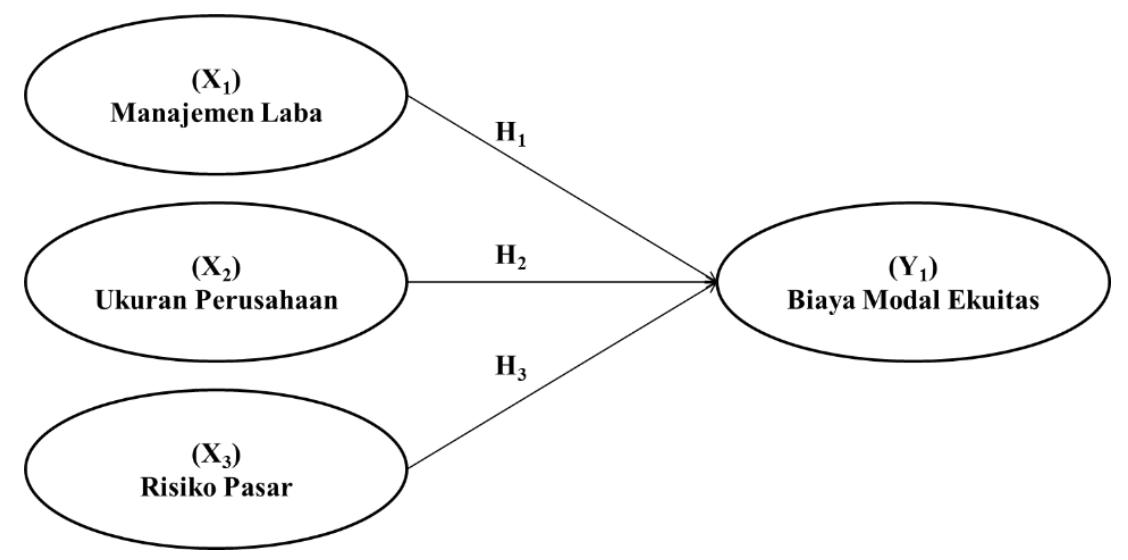

Sumber: Peneliti, 2019

Gambar 2. Model Penelitian 
Populasi dalam penelitian ini adalah perusahaan sektor property, real estate dan kontruksi bangunan yang terdaftar di BEI pada tahun 2014-2017 dengan jumlah sebanyak 47 perusahaan. Teknik purposive sampling digunakan untuk menentukan jumlah sampel dengan memasukkan kriteria sampel. Dengan jumlah sampel yang memenuhi kriteria sebesar 40 perusahaan. Kriteria yang digunakan sebagaimana termuat dalam Tabel 1.

Tabel 1

Kriteria Pengambilan Sampel

\begin{tabular}{cl|c}
\hline NO & \multicolumn{1}{c}{ KRITERIA PENGAMBILAN SAMPEL } \\
\hline 1 & $\begin{array}{l}\text { Perusahaan sektor property, real estate dan konstruksi bangunan yang terdaftar di BEI } \\
\text { Tahun 2014 s/d. 2017 }\end{array}$ \\
2 & $\begin{array}{l}\text { Perusahaan sektor property, real estate dan konstruksi bangunan yang aktif } \\
\text { memperdagangkan saham selama tahun 2014-2017 }\end{array}$ \\
\hline \multicolumn{2}{l}{ Jumlah sampel yang memenuhi kriteria } & 160 \\
\hline Jumlah pengamatan selama tahun 2014-2017 & \multicolumn{1}{c}{ Sumber: data diolah }
\end{tabular}

\section{Instrumen Penelitian}

Untuk tetap konsisten dengan penelitian sebelumnya, pengukuran masingmasing variabel penelitian mengadopsi indikator yang digunakan oleh penelitian sebelumnya sebagaimana terinci dalam Tabel 2. Variabel dependen penelitian adalah biaya modal ekuitas (BME) yang diukur menggunakan formula yang dipakai oleh Wulandari et al. (2017). Pengukuran terkait variabel manajemen laba (Mala) dan ukuran perusahaan (Size) mengadopsi dari Rinobel dan Laksito (2015), sedangkan untuk variabel risiko pasar (Risk) menggunakan formula dari Hartono (2013).

Tabel 2.

Pengukuran Variabel Penelitian

\begin{tabular}{llc}
\hline VARIABEL PENELITIAN & \multicolumn{1}{c}{ DEFISINI } & PREDIKSI \\
\hline Biaya modal ekuitas (BME) & $\mathrm{ks}=\mathrm{R}_{\mathrm{f}}+\beta\left(\mathrm{R}_{\mathrm{m}}-\mathrm{R}_{\mathrm{f}}\right)$ & \\
Manajemen laba (Mala) & Akrual modal kerja $(\mathrm{t}) /$ penjualan $_{(\mathrm{t})}$ & + \\
Ukuran perusahaan (Size) & Ln(Total aset) & - \\
Risiko pasar (Risk) & $\beta_{i}=\frac{\sum_{t=1}^{n}\left(R_{i t}-\bar{R}_{i t}\right)\left(R_{M t}-\bar{R}_{M t}\right)}{\sum_{t=1}^{n}\left(R_{M t}-\bar{R}_{M t}\right)^{2}}$ & + \\
\hline
\end{tabular}

Sumber: Wulandari et al., (2017), Rinobel \& Laksito (2015), dan Hartono (2013).

\section{Teknik Analisis Data}

Data penelitian diolah menggunakan program SPSS untuk mendapatkan hasil regresi linier berganda. Sebelum analisis regresi, analisis statistik deskriptif dan uji asumsi klasik dilakukan terlebih dahulu. Analisis deskriptif menggunakan ukuran berupa frekuensi, rata-rata, median, modus, dan standar deviasi. Uji normalitas menggunakan uji kolmogorov-smirnov dengan signifikan di atas 0,05. Untuk uji asumsi klasik meliputi multikolinieritas yang ketahui dari nilai VIF atau tolerance, 
autokorelasi dengan metode durbin-watson, dan heteroskedastisitas dengan uji glejser (Ghozali, 2013). Adapun model persamaan regresi logistik sebagai berikut:

$$
\text { BME }=\alpha+\beta_{1} \text { Mala }+\beta_{2} \text { Size }+\beta_{3} \text { Risk }+e
$$

dimana, $b_{0}$ menunjukkan intersep dari persamaan regresi, dan $b_{1}, b_{2}$, dan $b_{3}$ adalah koefisien regresi dari biaya modal ekuitas (BME), manajemen laba (Mala), ukuran perusahaan (Size), dan risiko pasar (Risk).

\section{HASIL DAN PEMBAHASAN}

\section{Deskriptif Variabel}

Untuk mengetahui deskriptif tentang variabel-variabel penelitian ini maka digunakan statistik deskriptif. Analisis statistik deskriptif dilakukan untuk mengetahui nilai rata-rata (mean), minimum, maksimum dan standar deviasi dari masing-masing variabel. Untuk mengetahui gambaran umum mengenai data penelitian ini tampak pada Tabel 3 .

Tabel 3.

Deskripsi Variabel

\begin{tabular}{lcrrrr}
\hline \multicolumn{1}{c}{ Variabel } & N & \multicolumn{1}{c}{ Minimum } & Maximum & \multicolumn{1}{c}{ Mean } & \multicolumn{1}{c}{ Std. Deviation } \\
\hline Mala & 160 & -5.6630 & 2.6935 & .131712 & 1.7728346 \\
Size & 160 & 11.9049 & 18.4544 & 14.437940 & 1.4424801 \\
Risk & 160 & -6.6809 & 6.3833 & .395117 & 1.4078752 \\
BME & 160 & -1.0092 & 1.0057 & .099983 & .2152275 \\
\hline \multicolumn{5}{c}{ Sumber: Data yang diolah, 2019 }
\end{tabular}

Perusahaan property, real estate dan konstruksi bangunan mengeluarkan biaya modal ekuitas rata-rata 0,0999 atau 9,99\% dengan nilai minimum -1,009 dan nilai maksimum 1,006. Rata-rata 0,1317 perusahaan sektor ini menggunakan manajemen laba dengan nilai minimum -5,6630 dan nilai maksimum 2,6935. Untuk ukuran perusahaan sektor ini paling kecil adalah 11,9049 dan yang paling besar adalah 18,4544 dengan rata-rata 14,4379. Risiko pasar yang dihadapi oleh perusahaan property, real estate dan konstruksi bangunan rata-rata 0,3951 dengan nilai minimum -6,6809 dan nilai maksimum 6,3833.

\section{Asumsi Klasik}

\section{Uji Normalitas}

Pengujian dilakukan menggunakan uji K-S dengan nilai signifikan lebih dari 0,05 untuk menggambarkan data yang berdistribusi normal. Berdasarkan Tabel 4, nilai Asymp. Sig menunjukkan nilai 0,090 yang menunjukkan bahwa data telah berada dalam sebaran yang normal. 
Tabel 4.

Hasil Uji Normalitas dan Asumsi Klasik

\begin{tabular}{|c|c|c|c|c|}
\hline \multirow{2}{*}{ Model } & \multicolumn{2}{|c|}{ Collinearity Statistics } & \multirow{2}{*}{$\mathbf{T}$} & \multirow{2}{*}{ Sig. } \\
\hline & Tolerance & VIF & & \\
\hline $1 \mathrm{C}$ & & & 1.552 & .123 \\
\hline Mala & .990 & 1.010 & -.592 & .555 \\
\hline Size & .967 & 1.035 & .052 & .958 \\
\hline Risk & .971 & 1.030 & -1.718 & .088 \\
\hline \multicolumn{5}{|c|}{ a. Dependent Variable: BME } \\
\hline Asymp. Sig. (2-tailed) & & & $90^{\mathrm{c}}$ & \\
\hline Durbin-watson & & & 122 & \\
\hline
\end{tabular}

\section{Uji Multikolinieritas}

Untuk mendeteksi ada atau tidaknya korelasi antarvariabel independen, maka uji multikolinieritas dilakukan. Pengujian ini melihat nilai VIF dan tolerance dari masing-masing variabel. Dalam Tabel 4 memperlihatkan bahwa variabel independen bebas dari multikolinieritas dengan nilai VIF di bawah 10 dan di atas 0,1 untuk nilai tolerance. Adapun hasil pengujian ini terlihat dalam Tabel 4. Hasil tersebut menunjukkan bahwa seluruh variabel independen tidak saling berkorelasi karena nilai VIF dan tolerance telah memenuhi kriteria.

\section{Uji Autokorelasi}

Data time series seperti penelitian ini seringkali terjadi gejala autokorelasi. Untuk mengujinya, pendekatan durbin-watson diperlukan untuk mengetahui apakah ada variabel pengganggu periode saat ini dengan sebelumnya. Sebagaimana terlihat dalam Tabel 4 bahwa data penelitian bebas dari autokorelasi. Lebih rincinya ada pada Gambar 3 di bawah ini. Di mana nilai DW hitung 2,122 berada diantara nilai dU sebesar 1,7798 dan 4-dU sebesar 2,2202 atau dU < dw < 4-dU $(1,7798<$ $2,122<2,2202)$

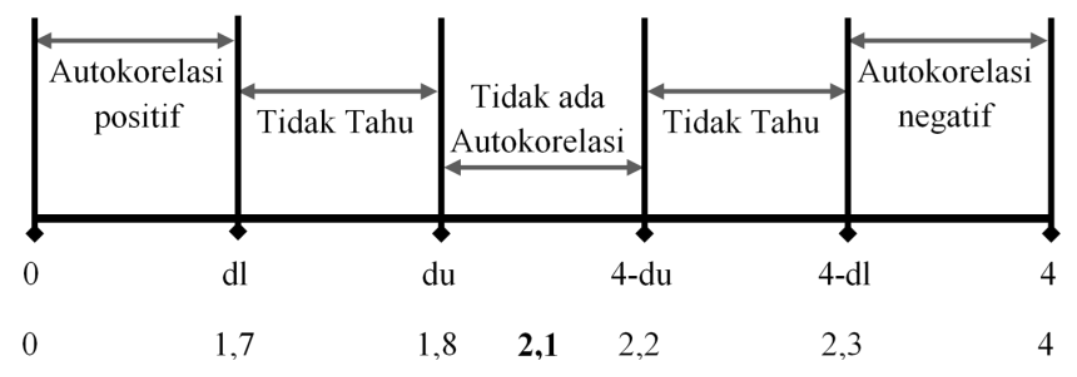

Sumber: Peneliti, 2019

Gambar 3. Posisi DW Hitung 


\section{Uji Heteroskedastisitas}

Model regresi yang baik harus homoskedastisitas, dimana ada kesamaan variance residual dari pengamatan satu ke pengamatan lainnya. Pengujian dilakukan menggunakan uji glejser dengan signifikansi lebih dari 0,05. Berdasarkan Tabel 4 menunjukkan nilai signifikan dari masing-masing variabel lebih dari 0,05 sehingga model penelitian ini memiliki nilai variance yang sama.

\section{Analisis Regresi Linier Berganda}

Berikut hasil yang terdapat pada Tabel 5 hasil uji regresi berganda, maka diperoleh persamaan regresi linear berganda sebagai berikut:

$$
\mathrm{BME}=\text { 0,122 + 0,025 Mala - 0,004 Size + 0,086 Risk + e }
$$

Tabel 5.

Hasil Regresi Linier Berganda

\begin{tabular}{llrrr}
\hline \multirow{2}{*}{ Model } & \multicolumn{2}{c}{$\begin{array}{c}\text { Unstandardized } \\
\text { Coefficients }\end{array}$} & $\begin{array}{c}\text { Standardized } \\
\text { Coefficients }\end{array}$ \\
\cline { 2 - 5 } & \multicolumn{1}{c}{ B } & Std. Error & \multicolumn{1}{c}{ Beta } \\
\hline $1 \quad$ C & .122 & .143 & .206 \\
& Mala & .025 & .008 & -.028 \\
& Size & -.004 & .010 & .560 \\
\multicolumn{2}{c}{ Risk } & .086 & .010 & \\
\hline \multicolumn{5}{c}{ a. Dependent Variable: BME } \\
\hline \multicolumn{5}{c}{ Sumber: Data yang diolah, 2019 }
\end{tabular}

Berdasarkan persamaan angka di atas, interpretasinya sebagai berikut.

1. Nilai konstanta sebesar 0,122 artinya apabila variabel manajemen laba, ukuran perusahaan dan risiko pasar dianggap konstan (bernilai 0), maka nilai biaya modal ekuitas sebesar 0,122 .

2. Nilai koefisien regresi manajemen laba adalah sebesar 0,025 yang memiliki arti bahwa manajemen laba mempunyai pengaruh terhadap biaya modal ekuitas dengan arah koefisien positif, sehingga jika nilai manajemen laba meningkat sebesar $1 \%$, maka biaya modal ekuitas akan mengalami peningkatan sebesar $0,025 \%$.

3. Nilai koefisien regresi ukuran perusahaan adalah sebesar $-0,004$ dengan tingkat signifikansi $0,678>0,05$ yang memiliki arti bahwa ukuran perusahaan tidak berpengaruh terhadap biaya modal ekuitas.

4. Nilai koefisien regresi risiko pasar adalah sebesar 0,086 yang memiliki arti bahwa risiko pasar mempunyai pengaruh terhadap biaya modal ekuitas dengan arah koefisien positif, sehingga jika nilai risiko pasar meningkat sebesar $1 \%$, maka biaya modal ekuitas mengalami peningkatan $0,086 \%$.

\section{Pengujian Hipotesis}

\section{Koefisien Determinasi}

Koefisien determinasi digunakan untuk mengetahui korelasi keseluruhan model dalam menjelaskan variabel dependen yang diteliti. Berdasarkan Tabel 6 
menunjukkan bahwa nilai koefisien determinasi (Adjusted $R^{2}$ ) sebesar 0,326 artinya bahwa biaya modal ekuitas perusahaan dipengaruhi oleh manajemen laba, ukuran perusahaan, dan risiko pasar sebesar $32,6 \%$ dan sisanya $67,4 \%$ dipengaruhi oleh variabel lain yang tidak masuk dalam penelitian.

Tabel 6.

Hasil Pengujian Hipotesis dan Koefisien Determinasi

\begin{tabular}{|c|c|c|c|}
\hline \multicolumn{2}{|c|}{ Model } & \multirow[t]{2}{*}{$\mathbf{T}$} & \multirow{2}{*}{$\frac{\text { Sig. }}{.394}$} \\
\hline 1 & $\mathrm{C}$ & & \\
\hline & Mala & 3.148 & .002 \\
\hline & Size & -.416 & .678 \\
\hline & Risk & 8.468 & .000 \\
\hline \multicolumn{4}{|c|}{ a. Dependent Variable: BME } \\
\hline \multicolumn{2}{|c|}{ F-Statistics } & 26.604 & $.000^{\mathrm{b}}$ \\
\hline \multicolumn{2}{|c|}{ Adjusted R Square } & & .326 \\
\hline
\end{tabular}

\section{Uji Parsial}

Untuk mendeteksi adanya pengaruh atau tidak antara faktor penentu dengan variabel dependen secara parsial, maka uji t dilakukan. Berdasarkan Tabel 6 menunjukkan hasil pengujian secara parsial sebagai berikut.

1. Variabel manajemen laba menunjukkan nilai t hitung sebesar 3,148 dengan signifikansi 0,002. Karena $t_{\text {hitung }}>t_{\text {tabel }}$ yaitu sebesar 3,148 $>1,6547$ dengan probability $0,002<0,050$ sebagaimana ditunjukkan dalam Gambar 4, maka $\mathrm{H}_{\mathrm{a}}$ diterima dan $\mathrm{H}_{\mathrm{o}}$ ditolak artinya secara parsial variabel manajemen laba berpengaruh positif dan signifikan terhadap biaya modal ekuitas.

2. Variabel ukuran perusahaan menunjukkan nilai $\mathrm{t}$ hitung sebesar $-0,416$ dengan signifikansi 0,678. Karena $\mathrm{t}_{\text {hitung }}<\mathrm{t}_{\text {tabel }}$ yaitu $-0.416<1,6547$ dengan probability 0,678 > 0,050 sebagaimana ditunjukkan dalam Gambar 5, maka $\mathrm{H}_{\mathrm{o}}$ diterima dan $\mathrm{H}_{\mathrm{a}}$ ditolak artinya secara parsial variabel ukuran perusahaan tidak berpengaruh terhadap biaya modal ekuitas.

3. Variabel risiko pasar menunjukkan nilai t hitung sebesar 8,486 dengan signifikansi 0,000. Karena t hitung > t tabel sebesar 8,486 > 1,6547dengan probability $0,000<0,050$ sebagaimana ditunjukkan dalam Gambar 6, maka $\mathrm{H}_{\mathrm{a}}$ diterima dan $\mathrm{H}_{\mathrm{o}}$ ditolak artinya secara parsial variabel risiko pasar berpengaruh positif dan signifikan terhadap biaya modal ekuitas.

\section{Uji Simultan}

Uji simultan (uji F) membandingkan antara nilai $F_{\text {hitung }}$ dengan $F_{\text {tabel }}$, maka dapat diketahui apakah variabel independen secara bersamaan berpengaruh terhadap variabel dependen. Pengujian pada penelitian ini adalah menggunakan tingkat signifikansi 5\% (0,05). Dari Tabel 6 dilihat bahwa nilai $\mathrm{F}_{\text {hitung sebesar }}$ 26,604. Dapat disimpulkan bahwa $F_{\text {hitung }}>F_{\text {tabel }}$ yaitu 26,60 $>2,66$ dan berada di daerah $\mathrm{H}_{\mathrm{o}}$ ditolak dan $\mathrm{H}_{\mathrm{a}}$ diterima sebagaimana terlihat dalam Gambar 7 . 
Sedangkan nilai signifikansi uji $\mathrm{F}$ yaitu 0,000 lebih kecil dari 0,05 maka menunjukkan adanya pengaruh yang signifikan manajemen laba, ukuran perusahaan dan risiko pasar secara simultan terhadap biaya modal ekuitas.

\section{Pembahasan}

\section{Manajemen Laba Terhadap Biaya Modal Ekuitas}

Secara parsial variabel manajemen laba berpengaruh positif dan signifikan terhadap biaya modal ekuitas. Hasil ini memperlihatkan bahwa motif manajemen laba yang dilakukan oleh perusahaan dapat mengakibatkan besar atau kecilnya biaya modal ekuitas yang dikeluarkan perusahaan. Mengingat tujuan dari motif manajemen laba perusahaan adalah mengendalikan informasi laba sesuai keinginan manajer perusahaan, yaitu dengan cara memaksimalkan atau meminimalkan laba. Perilaku manajemen seperti akan memengaruhi kebijakan perusahaan dalam hal pembagian dividen yaitu tinggi atau rendah dividen yang akan dibagikan. Ketika motif manajemen laba dilakukan untuk meningkatkan laba seakan-akan terlihat tinggi, maka perusahaan telah menjanjikan dividen yang lebih tinggi kepada investor. Dividen yang dibayarkan ini merupakan biaya modal ekuitas yang dikorbankan oleh perusahaan atas modal yang diterimanya dari investor. Hal sebaliknya, ketika motif manajemen laba untuk menampakkan laba perusahaan yang sedikit akan memungkinkan perusahaan membuat kebijakan pembagian dividen lebih rendah atau bahkan tidak membagikan sama sekali. Artinya, biaya modal ekuitas yang dikeluarkan perusahaan menjadi rendah. Hasil penelitian ini sejalan dengan penelitian sebelumnya yang dilakukan oleh Rinobel dan Laksito (2015).

\section{Ukuran Perusahaan Terhadap Biaya Modal Ekuitas}

Secara parsial variabel ukuran perusahaan tidak berpengaruh terhadap biaya modal ekuitas. Berdasarkan hasil penelitian memiliki arti ukuran perusahaan yang besar atau kecil tidak akan mampu memengaruhi biaya modal ekuitas. Ada kemungkinan investor kurang melihat ukuran perusahaan sebagai faktor dalam menentukan biaya modal ekuitas. Investor akan lebih meninjau dari berbagai aspek seperti memperhatikan kinerja perusahaan yang terlihat pada laporan keuangan perusahaan, nama baik perusahaan, serta kebijakan dividen sebelum memutuskan untuk menginvestasikan dananya pada perusahaan tersebut. Sehingga ukuran perusahaan tidak memastikan informasi kepada investor dalam menjamin return saham yang dapat diterima di masa depan. Hasil penelitian ini sejalan dengan penelitian sebelumnya yang dilakukan oleh Meythi et al. (2012) yang menggunakan proksi nilai pasar untuk mengukur ukuran perusahaan membuktikan tidak adanya korelasi antara ukuran perusahaan dan biaya modal ekuitas.

\section{Risiko Pasar Terhadap Biaya Modal Ekuitas}

Secara parsial variabel risiko pasar berpengaruh positif terhadap biaya modal ekuitas, ini menunjukkan bahwa semakin tinggi risiko pasar suatu perusahaan maka expected returns yang diminta investor (biaya modal ekuitas) semakin tinggi. 
Risiko pasar (beta) merupakan pengukuran suatu risiko sistematis perusahaan. Biasanya investor menggunakan nilai risiko pasar sebagai bahan pertimbangan mengukur risiko yang mungkin muncul sebelum memutuskan berinvestasi. Risiko pasar memengaruhi tingkat expected returns yaitu return minimal yang diharapkan oleh investor sebagai kompensasi atas risiko berinvestasi, dimana biaya modal merupakan tarif diskonto yang digunakan investor untuk menilaitunaikan arus kas dimasa mendatang. Dengan demikian, secara umum risiko pasar yang tinggi berakibat tingkat pengembalian (return) yang diminta investor juga tinggi dan ini berarti biaya modal ekuitas juga tinggi. Demikian pula sebaliknya, tingkat risiko pasar yang rendah tentu berdampak pada menurunnya return yang diminta investor yang juga berarti menurunnya biaya modal. Hasil penelitian ini sependapat dengan temuan Rika (2018), Fahdiansyah (2016) dan Wulandari et al., (2017) yang menyatakan simpulan yang sama terkait pengaruh risiko pasar terhadap cost of equity capital.

\section{E. SIMPULAN}

Sebagian besar penelitian menunjukkan pengaruh positif antara manajemen laba, ukuran perusahaan, dan risiko pasar terhadap biaya modal ekuitas perusahaan. Namun, variasi hasil juga tampak dibeberapa temuan penelitian. Apalagi untuk perusahaan sektor property, real estate dan konstruksi bangunan yang saat ini menjadi sasaran favorit untuk investasi. Penelitian ini bertujuan untuk menguji kembali dan menganalisis pengaruh manajemen laba, ukuran perusahaan dan risiko pasar terhadap biaya modal ekuitas pada perusahaan yang bergerak di sektor property, real estate dan konstruksi bangunan selama tahun 2014-2017. Pendekatan observasi dan dokumentasi dari laporan keuangan tahunan masing-masing perusahaan sampel dilakukan untuk pengumpulan data penelitian. Hasil penelitian menunjukkan bahwa manajemen laba dan risiko pasar berpengaruh positif terhadap biaya modal ekuitas, sedangkan ukuran perusahaan tidak berpengaruh terhadap biaya modal ekuitas. Besar atau kecilnya perusahaan tidak dapat menjelaskan perubahan biaya modal ekuitas yang dikeluarkan perusahaan. Temuan ini memberikan kontribusi keilmuan dan bahan kajian bagi perusahaan, peneliti selanjutnya, dan investor/masyarakat. Perusahaan dapat memperhatikan penerapan manajemen laba dan risiko pasar untuk menentukan strategi kebijakan ekuitas. Investor dapat mengambil pilihan yang tepat dengan mempertimbangkan kesehatan perusahaan melalui penerapan manajemen laba dan perubahan kondisi pasar. Para investor dapat memperhatikan informasi mengenai indikasi manajemen laba yang dilakukan perusahaan dan risiko pasar yang mungkin dihadapi sebelum memutuskan untuk berinvestasi. 


\section{DAFTAR PUSTAKA}

Adriani. (2013). Pengaruh Tingkat Disclosure, Manajemen Laba, Asimetri Informasi Terhadap Biaya Modal (Studi Empiris pada Perusahaan Manufaktur yang Terdaftar di BEI Tahun 2009-2011). Jurnal Akuntansi, 1(2), $1-27$.

Bouchet, A. (2010). Linking Outsourcing of Sponsorships to Athletic Department Strategy: An Agency Perspective. Journal of Sponsorship, 3(3), 277-283.

Daugherty, M. S., \& Jithendranathan, T. (2012). Underpricing of IPOs of U.S. Family ControlledBusinesses. International Research Journal of Finance and Economics, (90), 193-206.

Efrina, M., \& Faisal. (2017). Pengaruh Kualitas Laba dan Likuiditas Saham Terhadap Biaya Modal Ekuitas Pada Perusahaan Manufaktur di Bursa Efek Indonesia. Jurnal Ilmiah Mahasiswa Ekonomi Manajemen, 2(1), 31-50.

Fahdiansyah, R. (2016). The Influence of Voluntary Disclosure, Asymmetri Information, Stock Risk, Firm Size and Institutional Ownership Towards Cost of Capital ( COC ). Jurnal Aplikasi Manajemen (JAM), 14(2), 387-397.

Fahmi, I. (2012). Pengantar Pasar Modal (M. I. Ansari, ed.). Bandung: ALFABETA.

Fahmi, I. (2015). Manajemen Investasi: Teori dan Soal Jawab (2nd ed.; G. Sartika, ed.). Jakarta: Salemba Empat.

Farandani, B., \& Margasari, N. (2016). Fenomena Saham Tidak Aktif dan Saham Aktif di Bursa Efek Indonesia. Jurnal Manajemen Bisnis Indonesia (JMBI), 5(4), 413-424.

Ghozali, I. (2013). Aplikasi Analisis Multivariate dengan Program SPSS 21 (7th ed.). Semarang: Badan Penerbit Universitas Diponegoro.

Hanafi, M. M. (2011). Dasar-dasar Manajemen Keuangan. Yogyakarta: BPFE.

Handayani, S. R., \& Shaferi, I. (2011). Analisis Faktor-faktor yang Memengaruhi Underpricing pada Penawaran Umum Perdana (Studi Kasus pada Perusahaan Keuangan yang Go Publik di Bursa Efek Jakarta Tahun 2000-2006). Performance, 14(2), 103-118.

Hartono, J. (2013). Teori Portofolio dan Analisis Investasi (7th ed.). Yogyakarta: BPFE-Yogyakarta.

Kurnia, L., \& Arafat, M. Y. (2015). Pengaruh Manajemen Laba dan Ukuran Perusahaan Terhadap Biaya Modal Ekuitas Pada Perusahaan Manufaktur yang Terdaftar di Bursa Efek Indonesia. Jurnal Ilmiah Wahana Akuntansi, 10(1), Hal 45-70.

Lei, Q., Lin, B., \& Wei, M. (2013). Types of Agency Cost, Corporate Governance and Liquidity. Journal of Accounting and Public Policy, 32(3), 147-172. https://doi.org/10.1016/j.jaccpubpol.2013.02.008 
Meythi, Martusa, R., \& Evimonita. (2012). Pengaruh Luas Pengungkapan Sukarela, Beta Pasar, dan Nilai Pasar Ekuitas Perusahaan Terhadap Cost of Equity Capital Pada Perusahaan Keuangan yang Terdaftar di Bursa Efek Indonesia. Proceeding Seminar Nasional Dan Call for Papers "Kesiapan Industri Perbankan Dan Bisnis Dalam Menghadapi Asean Economic Community 2015” Fakultas Ekonomi Universitas Stikubank Tanggal, 1-14.

Pramita, Y. D. (2016). Earnings Quality and Beta On Cost of Equity Capital. Jurnal Bisnis \& Ekonomi, 14(2), 123-131.

Rahayu, A., Hidayati, N., \& Mawardi, M. C. (2018). Pengaruh Nilai Pasar Ekuitas dan Risiko Sistematis Terhadap Cost of Equity Capital (Studi Empiris Pada Perusahaan Perbankan yang Terdaftar di BEI Tahun 2015-2016). E-JRA, 07(11), 32-45. https://doi.org/10.1186/1476-4598-10-45

Rebecca, Y., \& Siregar, S. V. (2012). Pengaruh Corporate Governance Index, Kepemilikan Keluarga, dan Kepemilikan Institusional terhadap Biaya Ekuitas dan Biaya Utang: Studi Empiris pada Perusahaan Manufaktur yang Terdaftar di BEI. Simposium Nasional Akuntansi XV, 2-28.

Rika. (2018). Pengaruh Pengungkapan Sukarela, Ukuran Perusahaan, Leverage , Manajemen Laba dan Risiko Pasar Terhadap Biaya Modal Ekuitas ( Studi Empiris Pada Perusahaan Sektor Industri Dasar dan Kimia yang Terdaftar di Bursa Efek Indonesia Periode 2012-2016 ). JOM, 1(1), 1-14.

Rinobel, B., \& Laksito, H. (2015). Pengaruh Pengungkapan Corporate Social Responbility (CSR), Ukuran Perusahaan, Financial Leverage dan Manajemen Laba Terhadap Cost Of Equity Perusahaan. Diponegoro Journal of Accounting, 4(2), 1-9.

Sanjaya, F. B. (2017). Pengaruh Auditor Spesialisasi Industri, Ukuran KAP, Audit Tenure, Kepemilikan Keluarga, dan Kualitas Laba Terhadap Cost of Equity. Jurnal Akuntansi Bisnis, XVI(1), 86-112.

Sukarti, \& Suwarti, T. (2018). Pengaruh Pengungkapan CSR, Asimetri Informasi, Ukuran Perusahaan, dan Kepemilikan Institusional Terhadap Cost of Equity. Prosding SENDI_U 2018,692-698.

Wulandari, E., Malikah, A., \& Mawardi, M. C. (2017). Pengaruh Tingkat Pengungkapan Sukarela dan Beta Pasar Terhadap Cost of Equity Capital (Studi Empiris Pada Perusahaan Manufaktur yang Terdaftar di BEI). Jurnal Riset Akuntansi, 6(10), 58-70. 